\title{
The Industrial Revolution and Birth of the Anti-Mercantilist Idea: Epistemic Communities and Global Leadership
}

\author{
Daniel J. Whiteneck, Ph.D. \\ Department of Political Science \\ University of Colorado at Boulder \\ Boulder, CO 80309-0333 \\ whitenec@colorado.edu \\ Copyright 1996 by Daniel J. Whiteneck.
}

\begin{abstract}
This paper seeks to offer a new perspective on the linkage between global leadership and the role of epistemic communities in international relations. The issue of bilateral trade liberalization between Great Britain and its trading partners rose to prominence on the global agenda in the 1700 s by the efforts of British political economists and merchants. These efforts were prompted by changes in economic relations brought about by the Industrial Revolution and its impact on the mercantile system. While this group was small in number and its interactions rudimentary by 20 th Century standards, it nonetheless met the qualifications specified by many scholars. It is further argued that such communities are linked to the exercise of global leadership in the long cycle model's phases of agenda setting and coalition building. They are started and based in the global leader, and are nurtured by the relatively open social and political structures of that leader. Evidence supporting this argument strengthens the long cycle model's explanatory power with regard to agenda setting, coalition creation, and the role of innovative solutions to global problems, and makes preeminence in knowledge-based communities another dimension of global leadership.
\end{abstract}

[Page 1]

Journal of World-Systems Research

". . mercantilism weakened among the more aggressive and competitively powerfiul manufacturers . . opposition to mercantilism finding powerful champions such as Arthur Young and Adam Smith in England and the Physiocrats in France." (1)

"In the face of uncertainty, a publicly recognized group with an unchallenged claim to understanding the technical nature of the regime's substantive issue-area was able to interpret for traditional decision makers facts or events in new ways and thereby lead to new forms of behavior." (2)

The shift in the European dominated world economy in the middle of the 1700 s to a more liberal trading system based on the norms of reduced tariffs, reciprocity, the reduction of restrictions on merchants, and the use of a most- favored-nation clause to include states 
into this trading community stands in marked contrast with the mercantilistic practices of the previous two centuries. The Industrial Revolution just beginning in Western Europe was already changing the global issue agenda. States, and powerful actors within them, were faced with a new set of problems with regard to international trade and economic growth as the certainty of the old mercantile rules were shaken by the effects of new technologies and trading interests created. In such an environment, the influence of a small group of British political economists and merchants would be decisive in helping to set the agenda for world politics.

This group formed a proto-typical epistemic community and is linked to the exercise of global leadership in the agenda setting and coalition formation phases of the long cycle model of world politics. It is based in the global leader, and is instrumental in diffusing new ideas and policies to other states, as well as helping to lay the groundwork for future cooperative actions by coalition members. Linking the role of epistemic communities to the exercise of global leadership means that leadership in such an environment will rest, not only on traditional

[Page 2]

Journal of World-Systems Research

material measures of power like military forces and macroeconomic factors, but also on a base of epistemic communities able to frame new issues and solutions to problems designed to benefit the global leader and its coalition partners.

This article proceeds with: 1 ) discussion of the concepts of global leadership that relate to the functions of epistemic communities, 2) examination of the characteristics of the epistemic community of the $1700 \mathrm{~s}, 3$ ) community impact on the policies of the governments of the trading community, and 4) utility of this approach for the study of current American foreign policy in an era of world politics that can easily be characterized as agenda setting.

\section{II.}

Leadership in world politics has been well defined by David Rapkin as the performance of some task or service for the world society, influencing the actions of others through persuasion, winning international economic and military competitions, and serving as a role model for other states in the provision of innovative political and social practices. (3)

During the agenda setting phase of world politics, global problems are defined, clarified, and prioritized. Epistemic Communities perform this task for the global political society. In a situation of uncertainty, they define the new problems faced by states and use their expertise to outline possible solutions. Without the capacity to coerce cooperation through the use of economic or political force, they exercise influence through the exchange and diffusion of ideas. Their ability to persuade political decision makers in the 
leading state, and then to diffuse policy choices to other states, depends on the solutions they offer to problems on the agenda.

Global leaders are those states who have won economic competitions to create worldwide trade networks, expand them during the industrial revolution, and institutionalize them through a framework of agreements and organizations among states. They have w on military competitions in global wars in which the social, political, and economic relationships purposefully developed over the years before the war have been the foundations for victorious coalition warfare. They have been states with the social and political structures which allow for and reward the actions of

[Page 3]

Journal of World-Systems Research

innovation by groups representing academia, religion, trade, and the sciences. In every competition, the ability to define the issues at stake and promote policies beneficial to the global leader and others has been the key to creating a coalition strong enough to win global wars and exercise governance of the world system afterwards. (4) All of these activities depend on non-coercive leadership, that is, on leadership demonstrated by a role model. Epistemic communities in a global leader serve as role models for similar groups in other states. They demonstrate that the relatively open economic, political, and social systems of the global leader are fertile ground for innovative solutions to problems faced by the world system, and that those solutions may benefit many states, not just one.

This definition of global leadership stands in contrast to the descriptions of hegemonic leadership provided by realists and capitalist world-economy theorists.

Realists with a historical perspective (Gilpin, Kennedy, and Holsti), argue that hegemonic states arise when one state increases its relative gross economic and financial power and is able to translate that power into politico-military power. (5) This state is able to overcome the systemic bias toward anarchy and equilibrium to set and enforce system wide rules governing the use of force and the flows of international trade.

The dominant outlook, which has encompassed both classical and neorealist writings since World War II, is that the period from 1648 to 1815 was characterized by power balancing among the European states that formed the heart of international politics. No one state met the realist criteria for hegemony until the onset of the Pax Britannica in 1815 .

The world-economy theorists (Braudel, Wallerstein, Chase-Dunn, Gills, and Gunder Frank) have also developed a clear understanding of hegemonic states within the larger system. (6) State behavior is driven by the expansion and development of the system's transnational capital, labor, and information markets. Fragmented political units (states) have competed for control of the core of this system and its concentration of capital, 
advanced production capabilities, skilled labor, and commercial networks. A hegemonic state is one that has emerged victorious from the armed struggle for that control, and has achieved the simultaneous dominance of the system's production, commercial, and financial resources. This state will aggressively support and expand the capitalist worldeconomy into new areas of peripheral exploitation.

In these models, the only hegemonic states have been: the Dutch from 1620 to 1650 , the British from 1815 to 1873 , and the United States from 1945 to 1968. Wallerstein, for example,

[Page 4]

Journal of World-Systems Research

holds that the 1700s were marked by core competition between France and Great Britain, and that it was not until the end of the Revolutionary and Napoleonic Wars that the issue of which state would control the core of the capitalist world-economy was settled.

This article is grounded in the long cycle tradition (see Modelski and Thompson), with its emphasis on problem solving and structured phases of global leade rship and global political evolution. (7) It acknowledges the importance of the processes of agenda setting and coalition creation to the rise of global leadership states.

Coming at the problem from this perspective concentrates attention on the period in question and how leadership is exercised in the processes mentioned above. It will also demand a broader defintion of leadership than has been put forward by the other global system perspectives. It is in this vein that the article proceeds to the role of epistemic communities, leadership, and problem solving.

Recent literature on epistemic communities helps to cement a connection between Rapkin's definition of leadership and the role of such communities in the world system. "An important response to adversity by parts of the political public, especially academics, professionals, and the intelligentsia, is to develop new ideas, including policy proposals. This is not a new phenomenon; troubled times often stimulate thinking." (8)

Agenda setting phases of world politics are situations of adversity, they are 'troubled times'. Power in the system is deconcentrated as the old governing coalition finishes executing its solutions to old agenda problems and starts to lose cohesion. States and other actors are challenged by new issues and may be ill prepared to meet them. In fact, they may be having trouble making sense of the rapid change they face.

Judith Goldstein, looking at the impact of ideas on trade policy in the United States, concluded that institutions are subject to inertia. (9) She argued that crises occurred when structures could not meet the demands of the international environment; they became malleable to new coalitions with alternative plans to "overcome the problems at hand." A 
crisis must be met by a supply of new ideas for restructuring policies to meet changing economic and political needs. The policies that sufficed to solve the structural problems during one cycle of world politics may be unsuited to a new agenda.

[Page 5]

Journal of World-Systems Research

During the agenda setting phase of world politics, there is not merely a power transition taking place, but a structural shift in the focus of the whole system and the actors within it. In these phases, the state of technology, the distribution of power, the force of domestic groups and processes, and political events are all changing rapidly. The result is that the attention of states and other actors must be changed. New assessments of what are systemic problems, and what can be done about them can find room for growth and development in this atmosphere. It is in just these conditions that Emmanuel Adler finds the optimal chances for the success of epistemic communities and their agendas. (10)

Some researchers have found that during such periods the growing demands of states for new ideas and information are matched by the growth of "sizeable and self-conscious" groups which frame issues and specify a range of options for policy makers. Peter Haas notes that these state demands are for information about social or physical processes, their interrelation to other processes, and the likely consequences of various actions requiring significant expertise. (11)

Leadership during the agenda setting phase of world politics is characterized by precisely the type of activities that are described above. It is a time of political and economic uncertainty in the world system, and the possession of a group of individuals capable of providing information based on theoretically sound ideas and backed up by knowledge garnered from research or ongoing interactions is an important facet of leadership.

The diffusion of an epistemic community's influence from within the global leader to other states in the system is an important part of the long process of coalition creation. It is integral to the non-coercive leadership needed to build a winning coalition at the global level. What must take place over time is a shift in the perceptions of interests by the global leader and other states with whom it cooperates. Peter Haas holds that the diffusion of new ideas can lead to new patterns of behavior and thus to international policy coordination because epistemic communities create channels from experts to experts and from experts to governments both within and between states. (12)

William Drake and Kalypso Nicolaidis, examining agenda setting within the GATT, concluded that the process was dominated by an Anglo-American core group that first posed the issues and then set the terms of discourse. (13) After this, the group grew to include experts from other states. It used its access to top policy makers to increase the credibility of policy options and to open up access to decision makers in other GATT member states. 
[Page 6]

Journal of World-Systems Research

Adler and Haas, editing a special issue of International Organization, argued that the influence of epistemic communities was exerted concurrently on an international level. The publication of information, exchanges at conferences, and other professional interactions all contributed to idea innovations that highlighted new expectations of state behavior. The creation of domestic and international coalitions around policy goals is the objective of decision makers in states aspiring to and achieving global leade rship. These coalitions are formed through both formal and informal contacts, the examination of national policy instruments and coordination in international organizations and multilateral agreements. (14)

Policy makers are learning from epistemic community members to alter expectations and interests. They proceed to try and convince other states to change their expectations and interests to conform to the new reality that has been described by the epistemic community. Leadership in this environment is not a function of economic coercion (which is subject to rapid change during agenda setting), nor is it a function of military coercion (as power is deconcentrated in the system); rather it is a matter of persuading others that the leader has correctly prioritized global problems, conceived credible alternative solutions to them, and provided information to support its claims to lead a coalition of states to their resolution. Once this position has been attained, the political skills of coalition leadership and the economic and military power of a state reaching for global leadership come into play.

The next aspect of leadership outlined by Rapkin, winning competitions, is not covered extensively in epistemic community literature. However, there are a few points that can serve to support the general arguments made here. Epistemic communities that are dynamic and growing during the policy formation process within the domestic structure of the world leader are those that are able to push outward into the international arena. Competition at the national level ties decision makers and community members to sets of ideas and processes that are then projected outward through formal and informal structures. Emmanuel Adler (15) and Fred Kaplan, (16) studying nuclear arms control policy and nuclear weapons strategy respectively, highlight this process at the national and international levels.

Peter Hall's work on the spread of Keynesian economic policies through the West during the first half of the 20th Century supports this general outline. (17) There was significant competition between competing economic theories to respond to a new set of economic problems faced by industrial democracies. There was the success of the epistemic communities in the

[Page 7]

Journal of World-Systems Research 
Anglo-American core and the subsequent expansion of the community and its policies to other states with similar systems. Those ideas were given legitimacy as the governing principles of macroeconomic policy for a generation following their triumph in the $1930 \mathrm{~s}$ and 1940s.

The last dimension of leadership raised by Rapkin was that of service as a role model for other actors. An epistemic community in a world leader demonstrates how to influence policy through the provision of new information and new ideas, how to gain access to policy makers, and how to translate influence into policy. This process is watched by similar actors in other states and, if proven successful, emulated by them in their own states. Interaction between communities in many states and between policy makers in those states will increase along with policy coordination.

A good example of this is Kaplan's study of the civilian nuclear strategists who created and shaped policy in the United States during the Cold War. They dominated technical and strategic information, had access to the highest levels of the government (both civilian and military), and carried out a steady education campaign with policy makers in the United States and its allies and with other strategists in allied states. Likewise, Robert Rothstein's study of international commodity negotiations concluded that stable international agreements rested on a pillar of shared analytical assumptions by experts which were used to inform and influence government negotiators in key states. (18)

If we take Rapkin's definition of leadership and a long cycle description of the agenda setting and coalition creation phases of world politics, we have a situation where the role of ECs can be significant. The exercise of leadership within this context is heavily influenced by the preeminent position held by epistemic communities within the future leader of the system. The existence of just such a community based in Great Britain at the start of the Industrial Revolution would prove to be instrumental in propelling the British to the leadership of a liberal trading coalition strong enough to replace the old mercantile system which had dominated the world economy with a more liberal system able to provide more absolute bene fits to Britain and its trading partners.

III.

[Page 8]

Journal of World-Systems Research

To describe the network of political economists and merchants of the early industrial revolution, it is important to have a clear understanding of the characteristics and functions of such communities. 
As a first point, epistemic communities do not have to be large in numbers to have influence in international relations. More important than numbers are: the levels of respect for members within their discipline, the ability of members to exercise influence within their discipline, and their ability to access actors in policymaking positions. (19)

Epistemic communities have four distinguishing characteristics which can be used as measurements for the British case: 1) shared normative value base and set of principled beliefs, 2) shared set of causal beliefs based on analysis of observed practices, 3) shared notion of evaluating and validating knowledge, and 4) common policy enterprises. (20)

The political economists and merchants who created a new way of thinking about international economic relations were bound by a common judgement that a high value should be placed on the creation of wealth by individuals and states. They argued that there was a connection between economic freedom and political freedom, and that the encouragement of such freedoms was to be valued. (21)

Adam Smith's "Wealth of Nations", published in 1776, was not the first work on liberalized trade, but was built on a foundation of continual interaction with other likeminded economists and earlier works in the field. Smith's work brought under one title a number of ideas that had been gaining legitimacy for the previous quarter-century. David Hume, Arthur Young, Josiah Tucker, the political-economy clubs of Scotland and England, the physiocrats in France, and the anti-Cameralists in the German states all provided component parts of what would be the most powerful economic message of the industrial era. These persons and groups argued that greater ec onomic freedoms at home and new international economic arrangements would create wealthier, more productive citizens, which would improve the social and political stability of the state and society. (22)

This community also shared a common view of the cause and effect relationships of the new world economic and political problems surrounding the industrial revolution. The cause of

[Page 9]

Joumal of World-Systems Research

those problems was the outmoded international mercantile system of trade: the concept of wealth based on amassing specie, the restriction of colonial markets, and state

monopolies in imports and exports. The effects of continuing the mercantile system in the face of rapidly changing technologies, import and export needs, and domestic economic actors were also agreed upon by community members.

To the Physiocrats in France, the system resulted in stagnant agricultural production, lower standards of living, a diminished state treasury, and political instability. (23) Josiah Tucker's "Essay on Trade" (1749) argued that continued adherence to strict mercantile 
principles would not increase trade or improve the commercial position of Britain in relation to her competitors. (24) The political economy clubs being founded in Scotland and England "experienced a keen sense of the inadequacy of certain accustomed ways of doing things ..." (25). The effects of the mercantile system were disincentives for inventions, decreases in imports needed for increasing production, and burdensome taxes. In the German states, the anti-Cameralists at the University of Gottingen concluded that the strict mercantilism of Prussia stifled economic growth and empowered the central state authorities. (26)

What information would community members use to judge the progress of the industrial revolution, the domestic reactions of states to its effects, and the progress of the international trading arrangements away from mercantilism toward liberalism? Without the formal structures and interactions familiar to epistemic community members they managed to agree to a remarkable degree on evaluative methods.

The progress of the revolution was judged in the states of Western Europe by the increasing use of machinery, the introduction of new inventions and manufacturing techniques, the percentage of the workforce engaged in agriculture versus industry, and the development of a supporting infrastructure. The leadership of the British in this area is unmistaken; they had forty of the first fifty steam engines developed, and they pioneered inventions like the flying shuttle, mechanized textile factories, ceramic ovens, modern cloth machines, and coke smelting. The British also had a larger percentage of their workers engaged in industry and other non- agricultural sectors than their rivals for leadership. $74 \%$ of the French workforce was in agriculture, compared to under $50 \%$ for the British. British workers were also much in demand throughout the continent because they were skilled at handling the new machinery. (27) Britain also led the way in creating an infrastructure to handle the increased economic activity. After 1750 , the number of turnpikes authorized by Parliament jumped from an average of eight per year to an average of thirty-five per year. Starting in 1758,165 new canals (spanning $600-700$

[Page 10]

Journal of World-Systems Research

miles) were constructed over the next forty years. (28)

The ability of states to react to the changing economy was judged on the taxes that were raised or lowered on economic activities, on the removal of regulatory restrictions with regard to internal trade or colonial trade, and the incentives provided for technological innovations. The merchant organizations in Manchester, Lancashire, Yorkshire, and Cheshire covered a broad range of business interests. They kept track of tax rates, lobbied for reduced transport fees, and argued for increased patent rights to encourage innovation and development. (29) Josiah Tucker's "The Elements of Commerce and Theory of Taxes" lent support to these efforts by drawing the theoretical connection between taxes, tolls, and regulations, and the growth of economic trade within the state. This was a key 
qualitative difference between Britain and France, where the Physiocrats were consistently fighting an uphill battle to remove internal restrictions. (30)

Trading arrangements were evaluated using raw numbers for the values of imports and exports, shipping traffic, the levels of tariffs, and the freedoms granted to merchants to operate in host countries. As an example, British shipping to Russia, her largest trading partner during the century, was carefully monitored and compared to the efforts of the French and the Dutch. From a figure of 375 in 1700, the number of British merchant ships serving Russia grew to 450 by 1760 , reached 1100 ten years later, and peaked in 1780 at 1400 (outnumbering the French and Dutch by a ratio of 7:1 each). (31) Similar records were kept by British merchants, envoys and travelling economists in Portugal, Spain, Holland, France, Savoy and Sardinia. Overall shipping carried by the British went from 317,000 tons in 1700 to $1,950,000$ tons by 1800 . The value of goods carried in British hulls also exploded from $12,000,000$ pounds to $62,000,000$ in the same period. (32)

The members of the community shared common policy objectives across the continent, both domestically and internationally. British political economists and merchants were represented in a growing number of political economy clubs. These clubs were the forerunners of the General Chambers of Manufacturers and the Manchester Committee. The objectives were framed by the theoretical work of the economists, who were able to make their hypotheses with a surfeit of information provided by and buttressed by the practical experience of the merchants. The policy objectives in Britain were: reciprocal trade treaties, increasing the supply of raw materials for the growing factories, encouraging capital investments, and insuring a stable tax structure to encourage business activity. (33)

[Page 11]

Journal of World-Systems Reseurch

The French Physiocrats, at the same time, were pushing for an end to arbitrary taxation of agricultural land, the removal of restrictions on the corn trade, reciprocal trade treaties, decreases in internal tariffs, tolls, and regulations, and increases in government infrastructure programs. (34)

Anti-cameralists, as the liberals in the German states were known, were centered in the historic trading cities of Hamburg, Bremen, Lubeck, and Hanover. They were supported by economists based at the University of Gottingen, who argued for the removal of restrictions on agricultural trade, expanding trade with Britain after the death of Frederick the Great, and reducing the power of the central state authorities over individual economic actors. (35)

In Russia, a Free Economic Society was established during the reign of Catherine the Great. The group was patterned after the clubs of England and Scotland, known to the 
Russian merchants who traded there. They lobbied for increased rights for merchants involved in overseas trade, for increased power in government for members of the merchant class, and for the reduction of the government's power to grant exclusive monopolies in many economic ventures. (36)

The Italian States saw the creation of a Chamber of Commerce in 1754 for the express purpose of improving infrastructures like roads, bridges, and ports. It also supported increased trade with Britain in the wine and woolens industries, as well as increasing the opportunities for foreign nationals to invest in Italy.

These examples demonstrate a remarkable degree of coordination across state and regional boundaries exhibited by similarly situated members of a growing community. The policy objectives they had in both the domestic and international arenas were specifically aimed at the uncertainty created by the new economic conditions.

IV.

[Page 12]

Journal of World-Systems Research

"The variety of economic transactions -- trade flows, labor flows, and technology transfers -- that occur between and among nation-states, are by no means random processes. Nor are the patterns of alliances and coalitions among nation-states a random occurrence."

"The social dimension of the international system, though less tangible than the economic and political dimensions, is nonetheless significant. It consists of patterns of recurrent interactions among rank-and-file citizens as well as elites from different countries."

"The cultural dimension of the international system, while even less visible than the social dimension, is of vital importance. It refers to the development and dissemination of a set of values, beliefs, and loyalties that can potentially serve either to integrate or to fragment the various actors comprising the international sy stem." (37)

The creation of a more liberal trading community as a response to the changing economic conditions of the Industrial Revolution serves as an example of the importance of the social and cultural dimensions of world politics. The coalition was deliberately created under British leadership, leadership that began with an epistemic community centered in Britain which developed and diffused a set of values and beliefs through the repeated interactions of a set of elites. Those values and beliefs were then translated into coordinated government policies by decision-makers in Britain and its trading partners.

This community was like a spider web, with Britain at the center. Its spokes reached out to France, Holland, Portugal, Russia, the German States, and the Italian States. Its full 
development would begin between 1740 and 1750 and reach a climax with the AngloFrench Commercial Treaty of 1786.

The economic theorists who started questioning the mercantile system were Josiah Tucker, David Hume, Roger Postlethwayt, and Adam Smith. Tucker and Hume corresponded often, exchanging ideas on their opposition to the mercantile conception of wealth, commercial

[Page 13]

Journal of World-Systems Research

monopolies, and exclusive trading relationships. (38) Tucker's essays were circulated among Hume's academic and social circles and found their way onto Adam Smith's library shelves. Postlethwayt wrote a universal dictionary of trade and commerce in 1751 (wherein he discussed the advantages of trade based on the principle of comparative advantage and the benefits of absolute over relative gains) which made the same rounds as Tucker's essays. (39)

These ideas resonated in two distinct groups, the political economy clubs of merchants and the more sophisticated circles of the Royal Society. In 1752 the political economy club of Glasgow, run by Andrew Cochrane, recruited a young professor named Adam Smith. This club was already lobbying for the removal of many restrictions on colonial trade and offered a fertile ground for the ideas of the economists. The receptivity of merchants to new economic theories was supported by an educational system which stressed practical subjects like business administration and science, coupled with exchange programs between Scottish universities and schools on the continent. (40) This process of interaction between the theoretical and practical sides of international trade advanced Adam Smith's thinking on liberalized trade. By the 1770 s, the economists were able to use the practical experience of the merchants to support their theoretical work, and the merchants in clubs were exposed to the evolving ideas of the economists and used them to argue for significant changes in tax, trade, and investment policies. The clubs spread to Manchester, Lancashire, Yorkshire, Cheshire, and London, and culminated in the establishment of a General Chamber of Manufacturers of Great Britain in the $1780 \mathrm{~s}$. (41)

Smith's first book, Theory of Moral Sentiments, brought him to the attention of the sophisticated circles of Hume and the political elite represented in the Royal Society. Charles Townshend offered Smith a position as tutor for his stepson, and Smith took advantage of the position to tour the continent from 1764 to 1766 with his charge. He continued to work on "Wealth of Nations" during the tour, spending a year in Paris with Hume (who was serving as secretary to the Embassy). Hume introduced him to French intellectual society, including a visit with Voltaire in Geneva that sealed his standing as a serious political economist of international importance. (42) 
The approval of the Royal Society and its members was very important because of its unique position as a European social institution. The society had been established in 1662 to further the discovery and exchange of knowledge on a wide range of subjects throughout Britain. Its founding was followed within one hundred years by similar societies in Paris, Berlin, Philadelphia, and St. Petersburg. From its beginning, the society maintained contacts between

[Page 14]

Journal of World-Systems Research

British and foreign scientists and writers, pursuing scholarly activities on an international basis. This was a tradition handed down from the founder, Sir Isaac Newton, and gave the society first place among intellectual circles in Europe. (43)

The first group on the continent to be influenced by the ideas of the British economists were the French Physiocrats. They had a common view of economic processes, of ideas about French society and its relation to other states, and a societal structure. Their school started with the Intendent of Commerce Gournay, who translated Tucker and supported fewer restrictions on trade and the lessening of customs duties. (44) Gournay's assistant Turgot maintained a correspondence with Tucker and met Smith at Physiocrat meetings in 1766. (45) Gournay and Turgot saw to it that Postlethwayt and Hume were translated into French in 1756, receiving money to support these projects from the English banker Cantillon. (46)

The structure of the Physiocrat society took form in 1757 under the hand of Francois Quesnay. Quesnay was a doctor, a member of the court, and a fellow of the Royal Society of Britain. In these positions he was exposed to the writings of the British and the French Intendants Gournay and Turgot. Quesnay turned to economic matters in 1757, arguing that if France concentrated on increasing its agricultural productivity and encouraged free trade, it could increase its wealth, replenish the national treasury, and create a more stable political system. Quesnay and Hume kept in contact and it was Quesnay who enlisted Adam Simith into the French political economy club. Quesnay agreed with Smith on the importance of economic freedom to the increased wealth of a society. Increased internal and external flows of commodities and capital were essential to this process. The overall wealth of society, represented by individual rational economic actors, was more important than protected royal monopolies, entrenched interest groups, and landed aristocrats. (47)

The ideas of British economists and merchants also had an impact on Russia, the country that would become Britain's largest trading partner in the second half of the century. There were twenty-eight merchant houses which were part of the British establishment in St. Petersburg by 1782 , and they also owned factories making rope, iron, indigo products, sugar refining, and cloth prints. These merchants enjoyed considerable privileges and positions of prominence in society. (48) During this period, Catherine the Great 
established the Free Economic Society, patterning it after the political economy clubs of Britain and France. She had been prompted to this by Russian merchants who had come into contact with their counterparts in British and Scottish ports and the salons of London and Paris. (49) Back in Russia, only the British were making

[Page 15]

Journal of World-Systems Research

extensive connections to Russian merchants and bankers outside of St. Petersburg, with the result that the provision of capital for Russian business ventures in the interior started to include the British. (50) This interaction between merchants, coupled with the establishment of the economic society, led to its becoming the center of a small, but influential, group of merchants and intelligentsia who started arguing for the same economic system which was propelling the British and the French to the forefront. (51)

At the other end of the spectrum lay the relationship between the British and the Dutch. Close ties had existed since the days of Elizabeth I and the wars for liberation against Phillip's Spain. Those ties had increased during the reign of William of Orange and the wars to contain the expansionist power of Louis XIV's France. William, married to Princess Mary, was offered the crown of England during the Glorious Revolution of 1688 , and he succeeded in merging the foreign policies of the two states to serve as the core of the anti-French alliances of the global wars lasting from 1688 to 1713 . After the end of the last of the Anglo-Dutch naval wars of the $1660 \mathrm{~s}$, the economies of the two states were drawn together by the commodity and capital flows between the growing power of London and the investment seekers of Amsterdam and Rotterdam. Liberalized regulations on capital flows were favored by bankers and merchants of both states. By the end of the 1750s one-third of the depositors in the Bank of Rotterdam were British, and the Bank of Amsterdam was supported by an influx of British capital to forstall a panic in 1763. On this two-way street, the Dutch were holding an estimated fifteen percent of Britain's national debt at the same time. (52) This practical push for changing economic rules was reinforced by educational exchanges between Scottish and Dutch universities, the translation and the sale of the works of Smith, Tucker, and Hume, and the interactions of the political economy clubs of Amsterdam and Rotterdam with those in Britain. (53)

The community was extended into the Italian States (including Venice, Florence, Savoy and Sardinia) through the efforts of the British representative to the court at Savoy and Sardinia, Lord Rocheford. Commerce in this region, gaining in importance since the Wars of Austrian Succession in 1740-1748, led to an increased opportunity for British influence. British mining companies in the region operated throughout this period, but were subject to the vagaries of traditional royal monopolies and shifting political forces. Working with local merchants in the shipping and import businesses, the British business owners and Lord Rocheford helped establish a local Chamber of Commerce. The chamber's members believed in improving the domestic infrastructure (especially port facilities) and increasing silver and wine exports. (54) 
[Page 16]

Joumal of World-Systems Research

The last places to be included in the epistemic community were the German States. While this may seem at odds with the strong dynastic ties that existed between England and the Hanoverians (who supplied the three Georges to be kings of England for most of the 1700 s), the influence of Frederick the Great's wars to solidify the continental position of Prussia was such that the ideas of the community were restricted to academic circles until Frederick's death. Frederick was determined to subordinate trade, commerce, and international contacts to wartime self-sufficiency directed from a highly centralized state structure. (55) Importing ideas and influences from Britain was also difficult in the face of British and Prussian clashes over the peace settlements at the end of the Seven Years war.

The inroads of the epistemic community were made in the ports of Hamburg, Bremen, and Lubeck because of their traditional role as entrepots to the interior of Central Europe, and in universities. At the University of Gottingen, The Wealth of Nations was translated by J.F. Schiller in 1776 , and given a very favorable review by J.G.H. Feder the next spring. Feder's fellow professor Georg Sartorius was so impressed that he started a course in political economy based on Smithian principles, and followed it up with a short tract titled, A Summary of State Economy: Based on Adam Smith's Principles, for use with Academic Lectures. Christian Kraus, then a visiting professor from Konigsberg, returned to its university and spread the Smithian ideas in political economy classes there. Isaak Iselin, another Gottingen professor, was also influenced by the Physiocrats. He shared the basic theoretical views on the sources of economic weal th, the role of the state in the economy, and the importance of expanding trade. At this time, the universities were much more liberal than Frederick's government, but his death in 1786 would be the watershed event for the rapid spread of the ideas of the epistemic community into the German States. (56)

V.

The acid test of an epistemic community is whether or not its views, which have circulated and come to dominance within an expert environment, come to the attention of policymakers and are then adopted as government policies by the states of the community. The common policy enterprise that has been the focus of intense community interaction must be

[Page 17]

Journal of World-Systems Research 
translated into specific policy objectives. This process takes time as policymakers "... absorb new meanings and interpretations of reality and adjust their willingness to consider new courses of action." (57) The outcome of the epistemic community activities of the middle 1700 s should be the adoption of new internal and external economic practices by the states involved.

In Britain, the ideas of Hume, Tucker, and Smith gained access to the highest levels of government through Pitt the Younger and Sir William Petty (the Earl of Shelbourne). Shelbourne, uniquely placed as minister responsible for colonial trade and foreign relations with Europe outside of the Baltic, was regularly corresponding and meeting with Tucker, Smith, and Richard Oswald. (58) Oswald was a leader in the manufacturer's committees and would be tapped by Shelbourne to serve as a negotiator with the Americans and the French on the end of the Revolutionary War and the creation of new economic relations with both states. In those negotiations, Oswald sat across the table from two members of the Philadelphia Society (modeled after the Royal Society in London) who were also well- versed supporters of the economic ideas of the epistemic community. (59) Pitt, a protege of Shelbourne's, had read the Wealth of Nations while still a student, had gone to work for Shelbourne, and had met Smith before rising to the leadership of the British government. He built on the framework laid down by the Earl when he became Prime Minister, engaging in sweeping negotiations with Britain's major trading partners in Europe, culminating in the Anglo-French Commercial Treaty of 1786 and a treaty with the United States in 1794.

Even before the revolutionary policies of Shelbourne and Pitt, there were changes in trading relations with European states from Russia to Italy. Between 1750 and 1783 tariffs were reduced on imports that were essential to the leading economic sectors of textiles and iron manufactures, foreign merchants were granted greater freedoms and shipping rights, and 'most favored nation' status was granted to states that reciprocated these actions.

In France, the Physiocrats enjoyed good access to economic policymakers and were successful in changing both domestic and trade policies. In 1757 Quesnay met with the first minister (Mirabeau), who believed that the government of France had to be decentralized and deregulated in order to encourage the creation of wealth. Other French officials supported Mirabeau and the Physiocrats, like the governor of Martinique who wrote a 1767 treatise on opening up trade in the Caribbean in order to, ". . allow each state to pursue its greatest natural advantage." (60) This book was the subject of Physiocrat meetings and applauded by Smith on his trip to France. It also found its way to the Russian ambassador to France and was forwarded 
home for the consideration of the new Free Economic Society of St. Petersburg. By 1786 Mirabeau and the Physiocrats were triumphant; domestic policy was changed to reduce internal tariffs that restricted the movement of goods, government regulations and the arbitrary powers of the inspectors were reduced, and the road and canal networks were improved, while foreign policy was highlighted by the signing of the Anglo-French treaty (negotiated by Royal Society member DuPont de Nemours) in the same year. (61)

In the Italian States, discriminatory tariffs were removed in 1754 and the rights of Britsh merchants against arbitrary changes in taxation were stengthened. Both of these measures preceded the signing of new commercial agreements that granted each nation 'most favored nation' status and expanded the role of the Royal Navy in the Mediterranean. (62)

The situation in Russia also improved in this period. British merchants were allowed to operate in the country's interior (Moscow, Tula, and Kursk), when merchants from other states were limited to St. Petersburg and other Baltic port cities. (63) This gave the British access to lucrative mining, timber, and grain industries, helping to fuel the process of industrialization underway in Britain. The 1766 commercial agreement between Britain and Russia contained a 'most favored nation' clause, increased the freedoms for merchants of both states, and vastly increased the value of Russian exports to Britain.

The most significant changes in state policies took place in Prussia after the death of Frederick the Great. A new generation of government officials would begin to put into practice the ideas of their university professors, men who had been a part of the epistemic community for the prevous ten to fifteen years.

August Lueder, graduate of Gottingen and court concillor in the 1790s, pushed forward policies that granted greater economic freedoms for individuals to trade overseas, accumulate capital, and put that capital to work anywhere in Europe. (64) Friedrich von Schrotter became minister in charge of East Prussia, succeeding in loosening restrictions on the grain trade. Theodor von Schon became the minister responible for agriculture in general. After travelling to England and spending three years at the University of Konigsberg, von Schon issued the Edict of Emancipation, which freed small farmers from onerous state restrictions on the sale of wheat. Hans von Auerswald served as concillor to the Chamber of War and Domains and was responsible for coordinating Prussia's trade policies during the Napoleonic Wars.

[Page 19]

Journal of World-Systems Research

All of the officials mentioned above were connected to professors who had been at Gottingen and influenced by the work of Adam Smith and the Physiocrats. The last three were students of Kraus: with von Schrotter making it a policy that officials working for him be certified as qualified by Kraus, von Schon studying under him for three years at 
Konigsberg, and von Auerswald living with Kraus in 1773 and keeping in close contact with him as a friend and correspondent for years. (65)

VI.

By expanding the study of epistemic communities with a historical dimension, is a richer and more detailed analysis of the requirements for global leadership provided? Is the connection between agenda setting and future global leadership strengthened?

Is there an appropriate analogy that can be drawn from the example of the Georgian transition to the case of the changing world system of the past twenty years and into the next period of agenda setting and coalition formation? What can we learn about: 1) agenda setting, 2) epistemic communities, and 3) coalition creation that students and practitioners of foreign policy can use as a guide for leadership of the unfolding cycle of world politics?

The global problems of the United States leadership of the world system after World War II were the reconstruction of a war-torn world, the provision of security for a small group of liberal, democratic capitalist states, and the restoration of a stable, open economic system linking North America, Western Europe, and East Asia. That period of leadership effectively ended in 1973 without a clear successor to leadership on the horizon.

American leadership has been effectively extended until the next macrodecision in approximately $2020-2030$, as the system enters a period of uncertainty about the defining issues of world politics and the coalitions that will be created to resolve those issues.

Like the situation in the middle of the $1700 \mathrm{~s}$, current world politics is once again in a phase of agenda setting. This phase is characterized by the rise of new problems in world politics, a rise in global disorder with an accompanying decline in the demand for order.

[Page 20]

Journal of World-Systems Research

The new problems facing the world political system are related to politics and society, security, and economics, but they are vastly different from traditional conceptions of these issue areas.

The first of these is the issue of consolidating and expanding the democratic community of states. Michael Doyle's work in this area is the best known of writings on the subject. (66) He identifies the problems to be handled in the near future as the protection of the members of the community and the fostering of conditions favorable to community growth. (67) The process has been underway for at least ten years, but it has reached the public consciousness in the past five years because of the democratic changes in the former Eastern bloc. These states, along with new democracies in Latin America and East Asia, have all sought to join a community of states charaterized by numerous political, 
economic, social, and security ties, both formal and informal. The decisions regarding the inclusion of new states into the community are important ones for the world system because in Doyle's words, "the liberal community of states is the single best hope for a stable, just, and secure international order." (68)

The second new problem on the agenda is to prevent the proliferation of weapons of mass destruction. If the warnings of President Kennedy that within twenty years there would twenty nuclear powers have not come true, it is not a cause for complacency. The nucle ar club has grown from five (United States, Russia, Britain, France, and China) to include India and Israel for sure, and most likely Pakistan and North Korea.

To prevent the rise of new nuclear states, the world system has used global treaties (Nuclear Non-Proliferation Treaty), regional treaties (Latin America Nuclear Free Zone), military actions (Iraq 1981 and 1991), and economic pressure (North Korea).

The world system, for so long focused on the bilateral competition between East and West on this issue, now faces problems of proliferation on nuclear, chemical, and biological weapons, and the missile systems needed to deliver them. The break-up of the Soviet Union led to the creation of three new nuclear powers, and the fear that they might solve their economic problems by selling such technology to other states. The success of the Persian Gulf War in 1991 did not completely deal with the problems of proliferation in Iran, Libya, Algeria, Syria, Saudi Arabia, or even Iraq. The prospects of North Korea possessing such weapons and delivery systems would increase the pressure on states like Taiwan, Japan, and South Korea to follow suit.

[Page 21]

Journal of World-Systems Research

The problem expands dramatically when it is combined with the export of materials, component parts, or whole systems by technologically advanced states from Europe, North America, the former Soviet bloc, Brazil, and Israel. This is a different problem than the one posed by the competition in all of these areas by the United States and the Soviet Union .

The third problem, while related to economics, is a far cry from the dominant economic concerns of the post-war era. I refer to the global, regional, and national problems arising out of the interaction between economic growth and environmental protection. The postwar period was dominated by issues of free trade, monetary stability, economic growth, assistance for industrial development, and the creation of jobs. An entire range of international organizations was created to handle these issues and American leadership of the system was exercised through the IMF, the World Bank, the GATT, the InterAmerican Development Bank, the Marshall Plan, and other programs too numerous to mention. In all of these matters, environmental concerns were subordinated to questions 
of growth and development. It has only been since the 1970 s that such questions have moved to the forefront of national and international economic deliberations.

At the national level, legislation on clean water, clean air, toxic wastes, and recycling was a hallmark of the $1970 \mathrm{~s}$ in industrial democracies. As these problems were proven to have effects that transcended national boundaries, states moved to regional solutions in the 1980s. Agreements on acid rain, pollution of the seas and rivers, the dumping of waste at sea, and whaling limits all came about when economic interests met with new environmental interests. As the 1980s came to a close and the 1990s began, the preservation of the rain forests, biodiversity, ozone depletion, and global warming all reached the agenda of global political problems.

Instead of a clear dominance by the political interests of national governments and their independent economic policies, these new issues raise questions of population growth, sovereign control of resources, the inclusion of new groups in decision-making, the development of new industries, types and uses of energy, and the preservation of resources that belong to no one state. Placing these on the global agenda mixes economics and the environment in a new way that changes old concepts of national interest, international responsibility, and development.

The importance of ideas in this process has gained increased attention and credibility in recent political science literature. (69) With regard to the three problems listed above, the United

[Page 22]

Journal of World-Systems Research

States is the nation with epistemic community leadership across all three areas. I will examine one of these in depth to illustrate this point; the problem of nuclear proliferation.

On the issue of non-proliferation, the United States has taken the lead on a number of fronts. With regard to chemical and biological weapons, the United States and the former Soviet Union signed agreements eliminating these classes of weapons. The United States took economic and military steps to stop their spread to countries like Libya and Iraq. It took diplomatic steps to reinforce the 1925 treaty of biological and chemical weapons control. In the aftermath of the Persian Gulf War, the United States arranged discussions with other industrial states to limit the export of equipment and materials that could be directed toward the production of these weapons.

The Non-Proliferation Treaty of 1968 included a proviso that the superpowers would seriously limit their nuclear arsenals as a quid pro quo for non-nuclear powers refraining from starting nuclear programs. The end of the cold war allowed this to happen. In an amazing turn around, the superpowers signed the INF ag reement in 1987, followed by the complete elimination of all nuclear weapons from Europe. They signed a START 
agreement which reduced strategic nuclear warheads from over 10,000 per side to 6,000 per side, and a follow up agreement which will drop that number to 3,000 warheads per side by the end of the century. (70) With this, the United States has turned its attention to limiting the nuclear programs of smaller, regional threats. Economic incentives were used to persuade the new states of Ukraine, Belarus, and Kazakhstan to end the nuclear programs they inherited with the fall of the Soviet Union. Military force was used to address the threat of Iraq becoming a regional nuclear power. Diplomacy, economic pressure, and the threat of force have all been used to stop the threat of a North Korean breakout from the 1968 treaty. (71)

An epistemic community of nuclear scientists, nuclear strategists, and responsible officials in governments and international organizations has grown and developed since the 1940s. The end of the Cold War in 1989 shifted the focus of this community from the superpower conflict and the prevention of nuclear war between them. The community now aims its attention at the dangers to world order posed by the uncontrolled spread of weapons of mass destruction. (72) In 1988 and 1989 there were only three articles each year on nuclear non-proliferation listed in "International Political Science Abstracts". In 1990 , that number jumped to nine; in 1991 it went to twelve; in 1992 it was up to thirteen; and by 1993 there were fifteen articles. These articles were written by members from every segment of the group listed above, from academics to policy makers.

[Page 23]

Journal of World-Systems Research

A community must exhibit a common understanding of the nature and causes of a policy problem on the agenda. The nature of the problem is agreed to be delineated as:

strengthening the powers of the IAEA, controlling the exports of nuclear or nuclearcapable technology, reducing the availability of plutonium and enriched uranium, and enhancing the security of states threatened by the proliferatrion efforts of outlaw states. The break-up of the USSR (with the attendant economic and social instability) has seriously loosened once strict controls on nuc lear materials, technology, and scientists. There has also been an increase in the global access to weapons information. This has coincided with improvements in miniturization, computerization, and technology that have reduced the costs of producing nuclear weapons. States wanting to go nuclear have seen the success of Israel, India, and Pakistan (and possibly North Korea) in avoiding international sanction in their proliferation efforts, and are bolstered in their belief that they might be the next to succeed. It is the combination of these factors that give rise to putting proliferation on the global agenda. (73)

This community has regular interchanges designed to enhance their own understanding of the problems, diffuse their ideas to others in the system, and make their assessments and alternative solutions known to decision makers. The Council on Foreign Relations (the pre-eminent foreign policy community in the United States after World War II), the Stanley Foundation, Harvard University (Avoiding Nuclear War Project), the Center for 
National Security Studies, and the Atlantic Council have all sponsored projects which have dealt with nuclear non-proliferation as their sole interest or made it a key part of their projects. (74) This is reinforced with annual reports from the International Institute for Strategic Studies and the Stockholm International Peace Research Institute, both of whom have shifted the focus of their nuclear research away from superpower conflict to proliferation. (75) It is exactly these types of programs that K. Subrahmanyam of the Pugwash Institute in India (a New Delhi-based security studies think tank) called for to increase interactions within the community in the wake of the Cold War.

The policy direction of the United States was changed in the 1990s, along with the agenda. In 1988 and 1989 there were only two hearings in Congress on nuclear proliferation. From 1990 to 1993 there were eleven hearings in the House and the Senate. The hearings took place in the Armed Services, Fore ign Affairs, Commerce, and Science and Technology Committees, and addressed the issues deemed to be the most important by community members. These issues included; controls on weapons -grade materials, the export of nuclear technology, ballistic missile proliferation, and cooperation with Russia and other states of the former Soviet

[Page 24]

Journal of World-Systems Research

Union to safely reduce weapons, stockpiles, and materials, and to enhance the security of their facilities. The Bush Administration took the lead in the aftermath of the Gulf War to expand the Nuclear Suppliers Group (NSG) to twenty-seven members. This group was founded in 1975 and based on the Western Suppliers Group founded in 1954. It was expanded to take into account the growth in the number of states producing materials and weapons systems that could be used in nuclear programs. (76) Also during the Bush Administration, South Africa and France agreed to sign the NPT and take a more active role in non-proliferation issues, and the People's Republic of China took its first steps toward cooperation with the NSG. Argentina and Brazil agreed to IAEA safeguards for the first time, and the EC supported the American position for more stringent export safeguards on dual-use technology.

The Clinton Administration continued to stress the importance of non-proliferation in its first year. The FBI opened up an office in Moscow to help the Russians run a joint operation to stop the spread of nuclear information, materials, and technology from Russia, Ukraine, and Kazakhstan. Increased economic aid to these states was conditioned on nuclear agreements on weapons destruction and non -proliferation efforts. John Deutch, the new Assistant Secretary for Defense, wrote that, "nuclear proliferation replaces the fear of superpower conflict." (77) The problem of proliferation has leapt to center stage in the past four years, with the 1995 conference on the renewal and revision of the Non-Proliferation Treaty at its heart. The interests of the United States, its allies, the newly independent states of the former Soviet Union, and the exporting states from China to Brazil will be pitted against the interests and aspirations of a few outlaw states. 
The challenge for the United States is to demonstrate leadership on supply-side controls and to work with other states to resolve regional conflicts in areas where nuclear proliferation is seen as the answer to the security dilemma.

VII.

Starting from a long cycle perspective, with a specific focus on the phases of agenda setting and coalition building, has made it possible to use Rapkin's definition of leadership to measure the effectiveness and role of epistemic communities. If agenda setting is defining, clarifying, and prioritizing new global problems and alternative solutions, then an examinaton of

[Page 25]

Journal of World-Systems Research

the role of epistemic communities is a good place to start. To avoid historical hindsight, it is necessary to analyze the social interactions of the members of the community and the policymakers of the states to correctly put ideas before outcomes.

In this case, community members wrote books, articles and pamphlets, organized academic groups and economic coalitions, and consistently interacted with government officials. They correctly assessed the changes being wrought by the industrial revolution on internal economies and external trade relations between states. They set the definitions for the new situation, provided clear methods of evaluating the situation and current government policies, and then laid out the alternative policy options (giving priority to certain political and economic values).

By using Rapkin's definition of leadership, we can set good parameters for assessing the effectiveness of the community. First, it clearly performed the task of agenda setting set forth above. Second, its members were able to persuade governments across Europe to change both internal and external policies in the face of long-standing contrary ideas about economic wealth and state power. Third, the ideas of the community (as well as the states putting them into practice) were successful in international competition against mercantilistic and nationalistic policies, highlighted by the defeat of Napoleonic France by a series of British-led coalitions. Lastly, the people and groups in Britain who were at the heart of the community, served as role models for other national communities and demonstrated how to effect changes in state policies.

Community members and policymakers of the 1740 to 1792 period were aware of the growing importance of the industrial revolution and its consequences for world politics. Today, members of epistemic communities and some policymakers are aware that one period of world politics has ended and a new one has begun. Students looking for the future course of world politics need to recognize that there is agenda setting going on 
now. Leadership in the new agenda areas will determine the near-future course of world politics and the determination of leadership of the world system.

\section{References}

[Page 26]

Journal of World-Systems Research

Adler, Emmanuel. "The Emergence of Cooperation: National Epistemic Communities and the International Evolution of the Idea of Nuclear Arms Control," International Organization, vol. 46, no. 1, 1992.

Adler, Emmanuel and Peter Haas. "Conclusion: Epistemic Communities, World Order, and the Creation of a Reflective Research Program," International Organization, vol. 46. no. 1.1992.

Bartlett, A.G. Cross and Karen Rasmussen, eds., Russia and the World of the 18th Century. Columbus: Slavica Publishers.

Berry, Christopher. The Idea of a Democratic Community. New York: St. Martin's Press.

Black, Jeremy. 1990. 18th Century Europe, 1700-1789. London: MacMillan and Company.

Blackwill, Robert and Albert Carnesale, eds. 1993. New Nuclear Nations: Consequences for US Policy. New York: Council on Foreign Relations Press.

Boorstein, Daniel. 1983. The Discoverers. New York: Random House.

Bowden, Witt and Michael Karpovich. 1937. An Economic History of Europe Since 1750. New York: American Book Company.

. 1937. An Economic History of Europe since 1750. New York: American Book Co.

Braudel, Fernand. 1984. The Perspective of the World: Civilization and Capitalism, 15th Century, Vol. 1-3. New York: Harper and Row Publishers.

Carpenter, Ted Galen, "A New Proliferation Policy," National Interest 28, Summer 1992.

Chase-Dunn, Christopher. 1983. "The Kernal of the Capitalist World-Economy: Three Approaches," in Contending Approaches to World System Analysis, William R. Thompson, ed. Beverly Hills: Sage Publications. 
[Page 27]

Journal of World-Systems Research

1989. Global Formation: Structures of the World Economy. Oxford: Blackwell Publishers.

Cross, Anthony. 1973. "The British in Catherine's Russia: A Preliminary Survey," in J.G. Garrard, ed., The 18th Century in Russia. Oxford: Clarendon Press.

Deutch, John. "The New Nuclear Threat," Foreign Affairs, 71 Fall 1992.

Doyle, Michael. 1978. The Old European Order, 1660-1800. Oxford: Oxford University Press.

. 1986. Empires. Ithaca: Cornell University.

. 1992. "An International Liberal Community," in Rethinking American's Security: Beyond Cold War to New World Order. New York: Norton.

Drake, William and Kalypso Nicolaidis. "Ideas, Interests, and Institutionalization: Trade in Services' and the Uruguay Round," International Organization, vol, 46, no. 1. 1992.

Dror, Yehezkel. 1986. Policy Making under Adversity. New Brunswick: Transaction Books.

Dunn, Lewis, "Four Decades of Nuclear Non-Proliferation: Some Lessons from Wins, Losses, and Draws," Washington Quarterly 13, Summer 1990.

. 1991. Containing Nuclear Proliferation. London: Brassey's.

Evan, William. 1981. Knowledge and Power in a Global Society. Beverly Hills: Sage Publications.

Gilpin, Robert, 1981. War and Change in World Politics. Cambridge: Cambridge University Press.

1987. The Political Economy of International Relations. Princeton: Princeton University Press.

Goldfarb, Jeffrey. 1992. After the Fall: The Pursuit of Democracy in Central Europe. New York: Basic Books.

Goldstein, Judith. "The Impact of Ideas on Trade Policy: The Origins of US Agricultural and Manufacturing Policies," International Organization, vol. 43, no. 1, 1989. 
[Page 28]

Journal of World-Systems Research

Goldstein, Judith and Robert Keohane, eds. 1993. Ideas and Foreign Policy: Beliefs, Institutions, and Political Change. Ithaca: Cornell University Press.

Haas, Ernst. 1989. When Knowledge is Power: Three Models of Change in International Organization. Berkeley: University of California Press.

Haas, Peter. "Introduction: Epistemic Communities and International Policy

Coordination," International Organization, vol. 46, no. 1. 1992.

Haley, K.D.B. 1988. The British and the Dutch: Political and Cultural Relations Through the Ages. London: George Phillip Publishers.

Hall, Peter. 1988. The Politics of Political Power of Economic Ideas: Keynesianism across Nations. London: George Phillip Publishers.

Harlow, Vincent. 1952. The Foundations of the Second British Empire: 1763-1793 vol. 1. London: Whitefriars Press.

Hasek, Carl William. "Introduction of Adam Smith's Doctrines," Studies in History, Economics, and Public Law, vol. 117, no. 2. 1925.

. 1925. "The Introduction of Adam Smith's Doctrines into Germany," Studies in History, Economics, and Public Law, vol. 117, no. 2. 1925.

Higgs, Henry, 1897. The Physiocrats. London: MacMillan and Company.

Holsti, Kalevi. 1991. Peace and War: Armed Conflicts and International Order, 1648 1989. Cambridge: Cambridge University Press.

Hubatsch, Walther. 1973. Frederick the Great of Prussia: Absolutism and Administration. London: Thames and Hudson Publishers.

Kaplan, Fred. 1983. The Wizards of Armageddon. New York: Simon and Schuster.

Kennedy, Paul. 1987. The Rise and Fall of the Great Powers. New York: Random House.

[Page 29]

Journal of World-Systems Research 
Kirchner, Walther. 1966. Commercial Relations Between Russia and Europe, 1400-1800. Bloomington: Indiana University Publications.

Lentin, A. 1973. Russia in the 18th Century. New York: Harper and Row Publishers.

Luard, Evan. 1992. The Balance of Power: The System of International Relations 1648 1815. London: MacMillan Company, Ltd.

Modelski, George. 1987. Long Cycles in World Politics. Seattle: University of Washington Press.

Modelski, George and William R. Thompson. 1988. Seapower and Global Politics, 14941993. Seattle: University of Washington Press.

Munro, George. 1988. "The Role of the Veksel in Russian Capital Formation: A Preliminary Inquiry," in R.P. Bartlett and A.G. Cross and Karen Rasmussen, eds. Russia and the World of the 18th Century. Columbus: Slavica Publishers.

Palma, Guiseppe Di. 1990. To Craft Democracies. Berkeley: University of California Press.

Pilat, Joseph and Robert Pindley, eds. 1990. Beyond 1995: The Future of the NPT Regime. New York: Plenum Press.

Rae, John. 1965. The Life of John Smith. New York: Augustus Kelley Publishers.

Rapkin, David. 1987. "World Leadership," in G. Modelski, ed. Exploring Long Cycles. Boulder: Lynne Rienner.

Reid, W. Stanford. 1954. An Economic History of Great Britain. New York: Ronald Press Company.

Rice, Geoffrey. 1989. "Lord Rochford at Turin 1749-1755: A Pivotal Phase in AngloItalian Relations in the 18th Century," in Jeremy Black, ed. Knights Errant and True Englishmen. Edinburgh: John Donald Publishers.

Russett, Bruce. 1993. Grasping the Democratic Peace: Principles for a post-War World. Princeton: Princeton University Press.

[Page 30]

Journal of World-Systems Research

Schuyler, Robert. 1931. Josiah Tucker: A Selection from His Economic and Political Writings. New York: AMS Press. 
Scott, W.R. 1937. Adam Smith as Student and Professor. Glascow: Glascow University Publications.

Simpson, John and Darryl Howlett, "Nuclear Non-Proliferation: The Way Forward," Survival 33, November- December 1991.

Subrahmanyam, K. "Preventing Proliferation of Nuclear Weapons: Forestalling 1995," Strategic Analysis 12, November 1988.

Thompson, William R. 1990. On Global War: Historical-Structural Approaches to World Politics. Columbia: University of South Carolina Press.

Wallerstein, Immanuel. 1989. The Modern World System, vols. 1-3. San Diego: Academic Press.

Waltz, Kenneth. Theory of International Politics. New York: Random House Publishers.

\section{Notes}

(1) Bowden, Witt and Michael Karpovich. 1937. An Economic History of Europe since 1750. New York: American Book Co. p. 78.

(2) Haas, Ernst. 1989. When Knowledge is Power: Three Models of Change in International Organization. Berkeley: University of California Press. p. 403.

[Page 31]

Journal of World-Systems Research

(3) Rapkin, David. 1987. "World Leadership," in G. Modelski, ed. Exploring Long Cycles. Boulder: Lynne Rienner. p. 132.

(4) Ibid.

(5) Gilpin, Robert. 1987. The Political Economy of International Relations. Princeton: Princeton University Press. Gilpin, Robert. 1981. War and Change in World Politics. Cambridge: Cambridge University Press. Holsti, Kalevi. 1991. Peace and War: Armed Conflicts and International Order, 1648-1989. Cambridge: Cambridge University Press. Kennedy, Paul. 1987. The Rise and Fall of the Great Powers. New York: Random House. Luard, Evan. 1992. The Balance of Power: The System of International Relations 1648-1815. London: MacMillan Company, Ltd. Waltz, Kenneth. Theory of International Politics. New York: Random House Publishers.

(6) Braudel, Fernand. 1984. The Perspective of the World: Civilization and Capitalism, 15th Century, Vol. 1-3. New York: Harper and Row Publishers. Chase-Dunn, 
Christopher. 1989. Global Formation: Stmictures of the World Economy. Oxford: Blackwell Publishers. Chase- Dunn, Christopher. 1983. "The Kernal of the Capitalist World-Economy: Three Approaches," in Contending Approaches to World System Analysis, William R. Thompson, ed. Beverly Hills: Sage Publications. Wallerstein, Immanuel. 1989. The Modern World System, vols. 1-3. San Diego: Academic Press.

(7) Modelski, George. 1987. Long Cycles in World Politics. Seattle: University of Washington Press. Modelski, George and Sylvia William R. Thompson. 1988. Seapower

[Page 32]

Journal of World-Systems Research

and Global Politics, 1494-1993. Seattle: University of Washington Press. Thompson, William R. 1990. On Global War: Historical-Stmictural Approaches to World Politics. Columbia: University of South Carolina Press.

(8) Dror, Yehezkel. 1986. Policy Making under Adversity. New Brunswick: Transaction Books. p. 65 .

(9) Goldstein, Judith. "The Impact of Ideas on Trade Policy: The Origins of US Agricultural and Manufacturing Policies," International Organization, vol. 43, no. 1, 1989. p. 32.

(10) Adler, Emmanuel. "The Emergence of Cooperation: National Epistemic Communities and the International Evolution of the Idea of Nuclear Arms Control," International Organization, vol. 46, no. 1, 1992, p. 106.

(11) Haas, Peter, "Introduction: Epistemic Communities and International Policy Coordination," International Organization, vol. 46, no. 1. 1992. p. 4.

(12) Ibid.

(13) Drake, William and Kalypso Nicolaidis. "Ideas, Interests, and Institutionalization: 'Trade in Services' and the Uruguay Round," International Organization, vol. 46, no. 1. 1992. p. 39.

[Page 33]

Journal of World-Systems Research

(14) Adler, Emmanuel and Peter Haas. "Conclusion: Epistemic Communities, World Order, and the Creation of a Reflective Research Program," International Organization, vol. 46. no. 1. 1992. p. 4. 
(15) Adler 1992.

(16) Kaplan, Fred. 1983. The Wizards of Armageddon. New York: Simon and Schuster. p. 385 .

(17) Hall, Peter. 1988. The Politics of Political Power of Economic Ideas: Keynesianism across Nations. London: George Phillip Publishers. pp. 361-91.

(18) Kaplan 1983.

(19) Adler and Haas 1992. p. 380.

(20) Ibid.p. 380.

(21) Boorstein, Daniel. 1983. The Discoverers. New York: Random House. pp. 656-57.

[Page 34]

Journal of World-Systems Research

(22) Bowden, Witt and Michael Karpovich. 1937. An Economic History of Europe Since 1750. New York: American Book Company.

(23) Higgs, Henry. 1897. The Physiocrats. London: MacMillan and Company. p. 19.

(24) Schuyler, Robert. 1931. Josiah Tucker: A Selection from his Economic and Political Writings. New York: AMS Press. p. 11.

(25) Bowden and Karpovich 1937. p. 110.

(26) Hasek, Carl William. "Introduction of Adam Smith's Doctrines," Studies in History, Economics, and Public Law, vol. 117, no. 2. 1925.pp. 61-72.

(27) Black, Jeremy. 1990. 18th Century Europe, 1700-1789. London: MacMillan and Company. pp. 46-50.

(28) Doyle, Michael. 1978. The Old European Order, 1660-1800. Oxford: Oxford University Press. p. 36.

[Page 35]

Journal of World-Systems Research

(29) Bowden and Karpovich 1937.p. 144. 
(30) Higgs 1897. p. 15.

(31) Kirchner, Walther. 1966. Commercial Relations Between Russia and Europe, 1400 1800. Bloomington: Indiana University Publications. p. 174.

(32) Reid, W. Stanford. 1954. An Economic History of Great Britain. New York: Ronald Press Company. p. 264.

(33) Bowden and Karpovich 1937. pp. 264.

(34) Higgs 1897. p. 34

(35) Hasek 1925. p. 121.

(36) Lentin, A. 1973. Russia in the 18th Century. New York: Harper and Row Publishers. pp. $90-1$.

[Page 36]

Journal of World-Systems Research

(37) Evan, William. 1981. Knowledge and Power in a Global Society. Beverly Hills:

Sage Publications. p. 17.

(38) Schuyler 1931.p. 14.

(39) Higgs 1897. p. 19.

(40) Reid 1954. p. 202.

(41) Bowden and Karpovich 1937. p. 145.

(42) Rae, John. 1965. The Life of John Smith. New York: Augustus Kelley Publishers. pp. 14-5.

(43) Evan 1992. pp. 15-16.

(44) Higgs 1897. p. 15.

[Page 37]

Journal of World-Systems Research

(45) Schuyler 1931. p. 16. 
(46) Higgs 1897. p. 90.

(47) Boorstein 1983. p. 660 .

(48) Cross, Anthony. 1973. "The British in Catherine's Russia: A Preliminary Survey," in J.G. Garrard, ed., The 18th Century in Russia. Oxford: Clarendon Press. pp. 242-45.

(49) Lentin 1973. p. 91

(50) Munro, George. 1988. "The Role of the Veksel in Russian Capital Formation: A Preliminary Inquiry," in R.P. Bartlett, A.G. Cross and Karen Rasmussen, eds., Russia and the World of the 18th Century. Columbus: Slavica Publishers. p. 562.

(51) Lentin 1973. p. 90-91.

(52) Haley, K.D.B. 1988. The British and the Dutch: Political and Cultural Relations Through the Ages. London: George Phillip Publishers. pp. 166-68.

[Page 38]

Journal of World-Systems Research

(53) Reid 1954. p. 203.

(54) Rice, Geoffrey. 1989. "Lord Rochford at Turin 1749-1755: A Pivotal Phase in Anglo-Italian Relations in the 18th Century," in Jeremy Black, ed. Knights Errant and True Englishmen. Edinburgh: John Donald Publishers. p. 345.

(55) Hubatsch, Walther. 1973. Frederick the Great of Prussia: Absolutism and Administration. London: Thames and Hudson Publishers. p. 345.

(56) Hasek, Carl William. 1925. "The Introduction of Adam Smith's Doctrines into Germany," Studies in History, Economics, and Public Law, vol. 117, no. 2. 1925. pp. 6172 .

(57) Adler and Haas 1992. p. 385.

(58) Scott, W.R. 1937. Adam Smith as Student and Professor. Glascow: Glascow University Publications. p. 110.

(59) Harlow, Vincent. 1952. The Foundations of the Second British Empire: 1763-1793 vol. 1. London: Whitefriars Press. pp. 448-49.

[Page 39]

Journal of World-Systems Research 
(60) Higgs 1897. p. 73.

(61) Ibid. p. 34

(62) Rice 1989. p. 100.

(63) Munro 1988. p. 563.

(64) Hasek 1925 . p. 78.

(65) Ibid. p. 117-121.

(66) Doyle, Michael. 1986. Empires. Ithaca: Cornell University. Russett, Bruce. 1993. Grasping the Democratic Peace: Principles for a post-War World. Princeton: Princeton University Press.

(67) Doyle, Michael. 1992. "An International Liberal Community," in Rethinking American's Security: Beyond Cold War to New World Order. New York: Norton. p. 151.

[Page 40]

Journal of World-Systems Research

(68) Ibid.

(69) Goldstein, Judith and Robert Keohane, eds. 1993. Ideas and Foreign Policy: Beliefs, Institutions, and Political Change. Ithaca: Cornell University Press.

(70) Subrahmanyam, K. "Preventing Proliferation of Nuclear Weapons: Forestalling 1995," Strategic Analysis 12, November 1988. pp. 809-824.

(71) Deutch, John. "The New Nuclear Threat," Foreign Affairs, 71 Fall 1992. p. 120-134.

(72) Dunn, Lewis, "Four Decades of Nuclear Non-Proliferation: Some Lessons from Wins, Losses, and Draws," Washington Quarterly 13, Summer 1990. pp. 5-18.

(73) Carpenter, Ted Galen, "A New Proliferation Policy," National Interest 28, Summer 1992. pp. 63-72.

(74) See: Blackwill, Robert and Albert Carnesale, eds. 1993. New Nuclear Nations: Consequences for US Policy. New York: Council on Foreign Relations Press. Pilat, Joseph and Robert Pindley, eds. 1990. Beyond 1995: The Future of the NPT Regime. New York: Plenum Press. 
[Page 41]

Journal of World-Systems Research

(75) Dunn, Lewis. 1991. Containing Nuclear Proliferation. London: Brassey's.

(76) Simpson, John and Darryl Howlett, "Nuclear Non-Proliferation: The Way Forward," Survival 33, November-December 1991. pp. 483-99.

(77) Deutch 1992, p. 120.

[Page 42]

Journal of World-Systems Research 